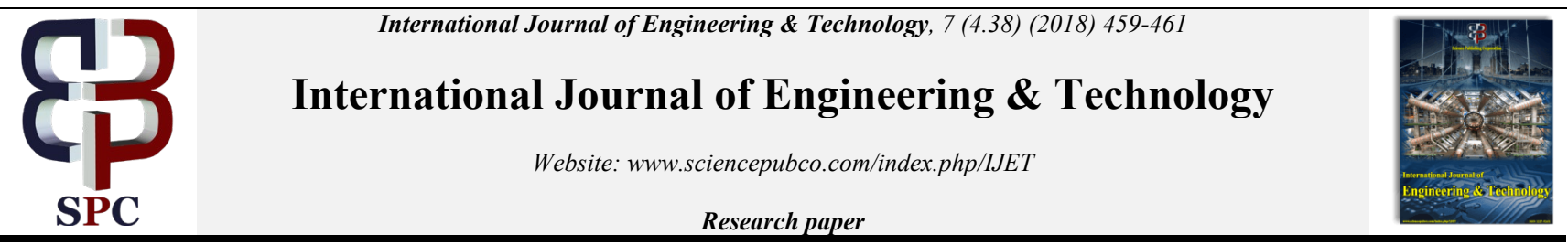

\title{
Street Theater in Modern Media Space
}

\author{
E. A. Semenova ${ }^{1 *}$ \\ ${ }^{1}$ Institute of Art Education and Cultural Studies of the Russian Academy of Education, Pogodinskaya Str., 8/1, 119121, Moscow, Russia. \\ *Corresponding author E-mail: 973381@mail.ru
}

\begin{abstract}
Street theater is viewed in modern media space as a reduced, repeatedly duplicated carnival area. M.M. Bakhtin's understanding of reduced forms of carnival laughter, which include humor, irony, sarcasm, is applied. The modern festival movement of street theaters in the beginning of the 21 st century is analyzed. It is proved that despite the fact that street theater actively uses new interactive means of media communication, containing various information (audio-visual, acoustic, computing, optical, imagery, artistic, scenic, etc.) and contributing to the acceleration of information dissemination and audience expansion, this form of theater is rapidly degenerating. Street theater is transformed into a serious socio-cultural game. But despite the fact that media technologies offer not excess but poverty (deficit) instead of extravagant human nature, the carnival origin is preserved not in replicable formats of street theater, but in informal communication between urban and rural youth. This makes it possible to talk about the preservation of modern man's vital need for street theater and carnival communication. The analysis of these issues is based on the views of M.M. Bakhtin, V.B. Shklovsky, Guy Debord, and J. Baudrillard.
\end{abstract}

Keywords: festival movement, media culture, street theater.

\section{Introduction}

Nowadays, festivals ("festival" - in French, Latin word "festivus" means "festive") are a common form of holding and organizing events of cultural life not only in the world cultural capitals but also in regional centers. The forms of carnival festivals, symposia, congresses are one of the most practiced integrated forms of educational tourism that are actively developing in Europe [1]. The rise of the festival movement of street theaters in Russia has been observed in the last two decades (the first two decades of the $21 \mathrm{st}$ century) [2]. The rather late attention to these phenomena in Russia is quite understandable. Historically, carnival culture stimulated by state programs was formed in European cities.

Increased interest in the festival movement of street theater in Russia in recent years is reflected in the intensive growth of theaters in this area. Only in 2016 in Russia, at least 16 international festivals of street theaters were held.

Street theater festivals become an object of scientific studies [310]. Street theater is very often considered in the context of the geopolitical situation in the world (settlement of interethnic conflicts); protest radical movement, propaganda [11, 12]; modern youth subculture $[13,14]$; student culture [15]; media communication $[16,17]$.

The paradox is that such a vivid manifestation of external signs of this phenomenon and sharply increased interest in it, as a subject matter of scientific study, may indicate both the deficit of street theater and its disappearance $[18,19]$.

Street theater doubles, which are not very similar to the original (spectacle, raus, open-air concert, performance, etc.), quite often create a sense of its presence in a conserved form doomed to eternal life in the media environment. Such doubles look better than the mortal original [18], as they are deprived of the opportunity to die.
This is largely due to media space. Khrenov points out that television has a hypertrophied suggestive (convincing) effect - it is an appeal to the subconscious of a person through direct suggestion or ritual [19]. Baudrillard notes a number of signs of the dead, pretending to be alive in modern culture: illusoriness, immaturity of the imaginary, etc. [18].

Some researchers are inclined to interpret media, television [20] in the categories of carnival. This point of view is not justified. Firstly, in the carnival everyone takes communion with carnival laughter, in which there are oppositions, a clear division into the bottom and top, the material and spiritual, the delimitation of reality and fiction. In the virtual world, these laws are violated. In this regard, the carnival hierarchy is deformed. The displacement of "carnival space" to the Internet does not reduce the aggression of the youth, its protest mood, but only increases the deficit of real-life dialogic communication. It seems important to turn to studying the properties of the media environment that violate the laws of space and time of street theater.

\section{Materials and Methods}

The analysis is based on materials on the development of street festival movement in Russia and Europe (scientific, practical ones). The historical-cultural analysis, statistics, comparative characteristics are applied. The properties of the media environment that transform carnival culture into anti-carnal culture are considered. Replication (in Late Latin "replicatio" means "repetition") is a property of the media environment that consists in the fact that the speaking of a particular interlocutor alternates with the speaking of another or others in the order of change or interruption. The modern language of media space, along with a human-oriented approach (when man adapts the media environment to himself) may fulfill the opposite function (adapt man to itself). The specificity of media communications (technical means for 
replicating socially important information, mass character, variability of communication means) is close to carnival culture by parody (the second voice). Diachrony is the most powerful communication property of the virtual environment (in Greek "dia" means "through" and "chromos" - time) may reduce the need for participation in street theater. Diatopicality and simultaneity in the virtual environment provide access and delivery of the information resource at any time. Multiplication (the invariability of the message, which is much repeated) deprives the street theater of its spontaneity. The nonverbal communication channels (paralinguistic sound codes, kinesthetic, ocular, auscultation ones) most accurately convey the nature of street theater, and they are also popular in virtual communication.

Several directions of street theater culture were analyzed for their coexistence with the virtual environment: street theater; festival of street theaters; various projects in the field of street theater development.

"Theatre-Ex", the performances of which depend on the local space (dumps, factories, rivers, bridges, fields, graveyards, squares, etc.), was considered as a street theater. The chronotope laws of M.M. Bakhtin on the continuity of art space and time were used for the analysis. In performances of Theatre-Ex there is a unity of "time-space" (M.M. Bakhtin used these words as one word), in which all events are chronologically inextricable with a certain place that generates a series of subsequent events. If the smallest detail of space is changed, the time will turn in a different way to the audience and the actor [21].

The legendary Burning Man Festival in the state of Nevada, USA, which dates back to 1986, was chosen as an example of a festival of street theaters. By 2018, this festival makes maximum use of all Internet means (announcements and rules of filing an application via the BRC multimedia application; it is allowed to have a laptop and a computer at the festival, but not a smartphone), filling out the application form and paying an organizational fee through the official website. At the same time, the organizers are still trying to defend their principles of escape from civilization, not substituting the street theater for its virtual double. Until now, the idea of the festival is based on the principles of radical inclusion, selfsufficiency, self-expression; donations; personal participation here and now; ecology. The festival was originally created by burners those who call the participants to express themselves through art and carnival. The number of participants in the Burning Man Festival by 2016 was about 75,000 .

Projects in the sphere of street theater culture were considered through the example of V.I. Polunin and his projects "Fools on the Volga", "Downy Garden", "Snow Show", "Caravan of the World", which clearly testify that the media space performs an auxiliary function in relation to the street theater, while media communications stimulate new creative forms and ways of interaction between street theater and the audience.

\section{Results}

Based on the comparison of the data on the development of street theater in various countries of the world, it can be stated that a street theater may not only develop in parallel with the development of Internet communications but also accumulate ideas that prevent the mechanical replication of its virtual copies-images.

The conducted analysis has revealed several general trends in the street theater development in the world: 1) the festival movement of street theaters develops in a single integration logic (the Latin word "integratio" means "integration") of the media space and street carnival culture; 2) in all countries, people consider street theater culture both as a protest expression and as a traditional, festive art; 3 ) each big city holds a large-scale annual traditional festival, which can unite a lot of local festivals; 4) the festival movement of street theaters supports the development of world tourism, especially ecotourism (the term was first used by the Mexican ecologist Hector Ceballos-Lascurain in the meaning of harmony between recreation and ecology); 5) the festival movement of street theaters develops through scientific understanding of the phenomenon of carnival culture.

\section{Discussion}

The author studied the processes of replication, diachrony, diatopicality, and simultaneity and found that while all of them activated the dissemination of information about street theaters in the media space, they might not generate an art event specific to street theater.

Replication is one of the few properties that allow creating and simulating an artistic event. It is widely and effectively used in social networks (Facebook, Instagram, etc.), in video blogs. The replication method is also used in street theater. Replication is a desire for dialogue, which can be seen in a childish egocentric speech, when a child begins to actively speak to himself in front of people. This is manifested in irony, becoming the main form of self-expression of adolescents, the youth in the Internet environment, in street theater.

\section{Conclusion}

The following conclusions have been made:

1.Modern communication means, media technologies modify the poetic-romantic orientation of street theater, which only externally actively integrates into the media space. Such integration transforms street theater from the carnival area into its reduced forms (reduction is understood in this case as narrowing down the complex to the simple). This leads to the commercialization of the most living projects in the field of street theater. Even the most ecotourism projects may be based on media technologies and replaced by Internet tourism.

2.The carnival area (street), reduced in the media, is deformed, turning society into a spectacle [22], which does not require personal physical presence.

3.The success, value of street theater today as an artistic event depends not only on the assessment of eyewitnesses, but also on "virtual votes" for or against, as well as on mechanical mailing.

4.Organizers and actors of street theaters and theaters of fire companies mainly consist of young people with theatrical, circus, acting, directing or humanitarian education. Fire theaters are characterized by a smaller percentage of young people with higher education, a younger contingent (adolescence). In the oldest street theaters, the average age of key actors is 30-45 years old. "Theatre-Ex", "Ognennie Ludi" (Fiery People), "Kamikaze-show", "Ognivo" can be considered as the most age-related theaters. All actors of fire theaters engage in buffoonery, clowning, ironic reflection of fire. In this regard, there is a risk of losing the poeticromantic orientation of the street theater.

\section{Acknowledgement}

The results set forth above were obtained within the framework of the State Assignment of the Ministry of Education and Science of the Russian Federation No. 27.7384.2017/8.9. While preparing this article, the author took into account the recommendations and proposals by Lubov G. Savenkova about the socio-cultural portrait of a modern child at different stages of childhood: age and individual features of the formation of artistic perception and thinking. L.G. Savenkova is Head of the Laboratory of Literature and Theater of the Federal State Budget Scientific Institution "Institute of Art Education and Cultural Studies of the Russian Academy of Education", Corresponding Member of RAE, Chief Researcher of the Federal State Budgetary Scientific Institution "Institute of Art Education and Cultural Studies of the Russian Academy of Education", Doctor of Pedagogy. While preparing this article, the author also took into account the recommendations and proposals by 
Elena F. Komandyshko about improving pedagogical ways of stimulating the creative process of education in the context of modernizing education. E.F. Komandyshko is Doctor of Pedagogy, Associate Professor, Chief Researcher of the Institute of Art Education and Cultural Studies of the Russian Academy of Education.

\section{References}

[1] Zach F \& Gretzel U (2012), Tourist-Activated Networks: Implications for Dynamic Bundling and EN Route Recommendations. Journal of Information Technology and Tourism, 13(3), 239-257.

[2] Harris S (2004), "Dancing in the Streets": The Aurillac Festival of Street Theatre. Contemporary Theatre Review, 14(2), 57-71. DOI: 10.1080/1026716041000128665.

[3] Moiseeva DP (2014), Sovremennyi ulichnyi teatr kak opyt demokratizatsii kul'tury (na primere Frantsii) [The Modern Street Theater as an Experiment in the Democratization of Culture (as exemplified by France)]. Vestnik Moskovskogo universiteta, Seriya 19: Lingvistika i mezhkulturnaya kommunikatsiya, 2, 95-101.

[4] Bokuradze DS (2015), Teatr kak gran goroda: khronotop, poetika i festivalnoe prostranstvo: avtoref. dis. ... kand. kulturologii [Theater as a Side of the City: Chronotope, Poetics and Festival Space (Ph.D Thesis Abstract)], Saransk.

[5] Kuzovenkova YuA \& Naumova OS (2015), "Festivalnoe prostranstvo" sovremennogo goroda, ego lokalnye formy i globalnye strategii ["Festival Space" of the Modern City, Its Local Forms and Global Strategies]. Yaroslavskii pedagogicheskii vestnik 5, 354-361.

[6] Gafar TV \& Lisitskii AV (2006), "Bolshoe neopoznannoe dvizhenie": Festivali v Volgograde kak instrument vliyaniya na gorodskuyu sredu i razvitie territorii ["Large Unidentified Movement": Festivals in Volgograd as a Tool of Influence on the Urban Environment and Development of the Territory]. Vestnik Assotsiatsii vuzov turizma i servisa, 10(1), 98-104.

[7] Pavlov AYu (2018), Ulichno-ploshchadnoi teatr kak kulturnyi fenomen: Uchebno-metodicheskoe posobie [Street-Area Theater as a Cultural Phenomenon: Study Guide], Omsk.

[8] Dubinkina EA \& Azarenkov LS (2016), Razrabotka kontseptsii festivalya ulichnykh iskusstv kak instrumenta povysheniya privlekatelnosti sovremennogo goroda [Development of a Concept of the Festival of Street Arts as a Tool to Increase the Attractiveness of the Modern City]. Traektoriya nauki, 2, 6(11).

[9] Fedorenko TN (2016), Festivali i ulichnyi teatr kak ikh sosatvlyayushchaya chast $\mathrm{v}$ esteticheskoi srede sovremennoi kultury Evropy i Rossii [Festivals and Street Theater as Their Integral Part in the Aesthetic Environment of Contemporary Culture of Europe and Russia]. Vestnik Voronezhskogo gosudarstvennogo universiteta, 2, 144-146.

[10] Zhukova OM (2017), Osobennosti vzaimodeistviya iskusstv v khudozhestvennom prostranstve festivalya [Features of the Interaction of Arts in the Artistic Space of the Festival]. Iskusstvo i kultura, $1(25), 13-17$

[11] Murray N, Street Theatre as Propaganda: Mass Performances and Spectacles in Petrograd in 1920. Academia https://www.academia.edu/14847279/Street_Theatre_as_Propagand a_Mass_Performances_and_Spectacles_in_Petrograd_in_1920.

[12] Eldhose AY (2014), Political Conscientisation through Street Theatre: A Study with Reference to Kalyanasaugadhikam: Research in Drama Education. The Journal of Applied Theatre and Performance, 9(4), 340-354. http://dx.doi.org/10.1080/13569783.2014.954811.

[13] Anderson E (2002), The Ideologically Driven Critique. American Journal of Sociology, 107(6), 1533-1550.

[14] Enderle M (2015), Mod - A Youth Subculture of the Past? Seminar: The Cultural Geography of Britain under Thatcher and Blair. Julius-Maximilians Universität Würzburg Neuphilologisches Institut.

[15] Komandyshko EF \& Semenova EA (2017), Educational Tourism: Adoption of Management Technologies in the Activity of Universities. Journal of Environmental Management and Tourism, 8, 6(22), 1183-1188.

[16] Banerjee A (2013), Evaluating the Role of Street Theatre for Social Communication. Global Media Journal - Indian Edition 4(2), 18.

[17] Bhatia U, Taking It to the Streets - A New Book on Leftist Theatre Group Jana Natya Manch. Time Out Mumbai.

[18] Baudrillard J (2013), Simulyakry i simulyatsiya [Simulacra and Simulation], Tula, 204
[19] Khrenov NA (2017), Kultura, kommunikatsiya i obrazovanie: vzaimodeistvie mezhdu informatsionnoi, prosvetitelskoi i suggestivnoi funktsiyami massovoi kommunikatsii [Culture, Communication and Education: Interaction between the Information, Educational and Suggestive Functions of Mass Communication], Kulturologicheskoe prosvetitelstvo $\mathrm{V}$ sovremennoi Rossii: Sbornik nauchnykh statei uchastnikov kruglogo stola X Kaganovskie chteniya (Sankt-Peterburg, RGPU im. A.I. Gertsena, 18 maya 2016 g.) [Culturological Enlightenment in Modern Russia: Collection of Scientific Articles of the Participants of the Round Table "X Kaganovsky Readings" (St. Petersburg, the Herzen State Pedagogical University, 18 May 2016)], St. Petersburg, 54-64.

[20] Tretyakov VT (2015), Teoriya televideniya. TV kak neoyazychestvo i kak karnaval. Kurs lektsii [Theory of TELEVISION. TV as Neopaganism and as a Carnival. Lecture Course]. Ladomir, Moscow, 664

[21] Semenova EA, Berladin AYu \& Zaldastanov AS (2017), Pokhozhdeniya ulichnogo teatra [The Adventures of a Street Theater]. Problema Khronotopa $\mathrm{v}$ sovremennykh nauchnykh issledovaniyakh: Mezhdunarodnyi kruglyi stol, posvyashchennyi M.M. Bakhtinu (Moskva, 19-20 aprelya 2017 goda, Moskva): Sbornik dokladov i statei [The Problem of the Chronotope in Modern Scientific Research: The International Round Table on M.M. Bakhtin (Moscow, April 19-20, 2017, Moscow): Collection of Reports and Articles]. FGBNU "IKhOiK RAO", Moscow, 252-268.

[22] Debord G (2009), Obshchestvo spektaklya [The Society of the Spectacle]. Logos, Moscow, 183. 